\title{
Pengaruh Kompetensi SDM dan Locus Of Control Pada Pencegahan Fraud dalam Pengelolaan Dana Desa
}

\author{
Ni Ketut Putri Pramesti Dewi ${ }^{1}$ \\ Fakultas Ekonomi dan Bisnis \\ Universitas Udayana, Indonesia. \\ Email: putripramestidewi@gmail.com
}

\author{
Ni Ketut Rasmini ${ }^{2}$ \\ Fakultas Ekonomi dan Bisnis \\ Universitas Udayana, Indonesia.
}

\begin{abstract}
ABSTRAK
Penelitian ini bertujuan untuk memperoleh bukti empiris mengenai pengaruh kompetensi sumber daya manusia dan locus of control pada pencegahan fraud dalam pengelolaan dana desa. Populasi yang digunakan adalah seluruh desa dinas di kota Denpasar sebanyak 27 Desa Dinas. Sampel penelitian diperoleh sebanyak 108 responden dengan menggunakan metode non probability sampling yaitu dengan menggunakan metode sensus. Teknik analisis data yang digunakan dalam penelitian ini adalah teknik analisis regresi linear berganda. Hasil penelitian ini menunjukkan bahwa kompetensi sumber daya manusia, dan locus of control internal berpengaruh positif pada pencegahan fraud dalam pengelolaan dana desa.

Kata Kunci : Kompetensi Sumber Daya Manusia; Locus Of Control; Fraud.
\end{abstract}

The Effect of Competence of Human Resources and Locus of Control on Fraud Prevention in The Village Fund Management

ABSTRACT

This research is aimed to acquire the empirical evidence of the influence of human resource competencies and locus of control on fraud prevention in the management of dana desa. This research has been selecting all of the 27 desa dinas in denpasar as the population. 108 respondent were collected as the sample. One of the non-probability sampling using census to obtained the data. Multiple linear regression technique analysis is applied to analyzing the data. This research shows that human resource competencies and locus of control, have given such an positive impact to the fraud prevention in the vilaage fund management.

Keywords: Human Resource Competencies ; Locus Of Control Fraud

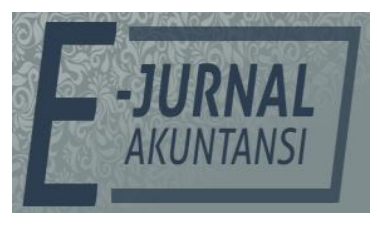

E-JA

e-Jurnal Akuntansi e-ISSN 2302-8556

Vol. 29 No. 3

Denpasar, Desember 2019

Hal. 1071-1082

Artikel masuk: 31 Oktober 2019

Tanggal diterima: 11 Desember 2019 


\section{PENDAHULUAN}

Undang-Undang Nomor 6 Tahun, 2014 Pasal 72 tentang Desa. Menjelaskan bahwa alokasi dana desa merupakan, dana perimbangan yang diterima kabupaten atau kota paling sedikit 10 persen dalam anggaran pendapatan belanja daerah (APBD) setelah dikurangi dana alokasi khusus yang digunakan untuk mendanai penyelenggaraan pemerintah desa, pelaksanaan, pembangunan desa, pembinaan dan pemerdayaan masyarakat. Dengan adanya UU tentang Desa ini akan memberikan perubahan secara signifikan dalam tata kelola pemerintahan desa. Pembagiann alokasi dana desa yang diterima oleh masingmasing desa di setiap wilayah berbeda-beda itu dikarenakan pemberian alokasi dana desa tersebut harus didasarkan pada jumlah penduduk, angka kemiskinan, luas wilayah desa. Peraturan Menteri Dalam Negeri No 113 Tahun 2014 tentang Pedoman Pengelolaan Keuangan Desa diharapkan dapat menjadi pedoman dalam pengelolaan dana desa karena didalamnya telah mencakup berbagai prosedur pengelolaan keuangan desa mulai dari perencanaan, pelaksanaan, penatausahaan, pelaporan sampai dengan pertanggungjawaban.

Kecurangan (fraud) merupakan tindakan yang dilakukan oleh seseorang atau kelompok yang secara sengaja untuk mendapatkan keuntungan dengan cara mendapatakan uang, aset dan lain sebagainya sehingga merugikan orang lain atau pihak tertentu (Aini et al., 2017). Kecurangan cenderung terjadi karena keinginan melakukan sesuatu untuk mendapatkan keuntungan menggunakan cara yang tidak jujur (Amiruddin dan Kartini, 2017). Kecurangan akuntansi sering terjadi karena adanya kesempatan yang terbuka lebar dalam organisasi, semakin lebar suatu kesempatan tercipta maka semakin besar pula kemungkinan terjadi kecurangan akuntansi (Dorminey et al., 2010).

Fraud Triangle Theory menjelaskan terdapat tiga faktor yang mendorong terjadinya tindakan kecurangan yaitu tekanan (pressure), peluang (opportunity) dan rasionalisasi (rationalization) (Cressy, 1953). Menurut GONE Theory terdapat empat faktor penyebab terjadinya tindakan kecurangan yang dilihat berdasarkan pandangan dari sisi perilaku manusia yaitu keserakahan, kesempatan, kebutuhan dan pengungkapan. Keserakahan berkaitan dengan adanya sifat serakah yang berada di dalam diri individu, kesempatan berkaitan dengan keadaan organisasi atau instansi atau masyarakat, yang memberikan peluang untuk individu dalam melakukan kecurangan, kebutuhan berkaitan dengan faktor-faktor yang dimiliki seseorang untuk menunjang hidupnya dan pengungkapan berkaitan dengan tindakan yang akan dihadapi oleh pelaku yang melakukan tindakan kecurangan (Manossoh, 2016). Fraud Triangle Theory dikembangkan menjadi Fraud Diamond dengan menambahkann satu elemen kualitatif yang diyakini memilikii pengaruh signifikan terhadap fraud yakni kemampuan (capability) sehingga menjadi empat elemen yang dikenal dengan Fraud Diamond (Wolfe dan Hermanson, 2014) .

Teori Keagenaan mejelaskan hubungan yang terdapat pada suatu kontrak yang terjadi antara principal dan agent. Dalam hal ini, principal menunjuk orang lain (agent) dalam melaksanakan suatu jasa dan memberikan wewenang kepada agent untuk mengambil keputusan (Jensen dan Meckling, 1976). Teori keagenan juga dapat diterapkan pada sektor publik (Oliveira dan Filho, 2017). Menurut 
(Lane, 2013), hubungan antara principal dan agent merupakan pendekatan yang penting dalam menganalisis komitmen kebijakan publik.

Teori Atribusi (Atribution Theory) menjelaskan tentang bagaimana seseorang menarik kesimpulan tentang apa yang menjadi dasar seseorang dalam melakukan suatu perbuatan atau memutuskan untuk berbuat dengan cara-cara tertentu (Rahmi dan Sovia, 2017). Teori Atribusi menjelaskan bahwa ketika individu mengamati perilaku seseorang, individu tersebut berupaya untuk menetukan apakah perilaku tersebut disebabkan secara internal atau eksternal (Robbins dan Judge, 2008). Pencegahan fraud penting dilakukan karena fraud dapat menghambat perkembangan suatu instansi dan juga dapat merusak moral dan sistem manajemen kerja para karyawan.

Fenomena kasus pengelolaan keuangan dana desa sudah banyak terjadi di Bali. Salah satunya pada tahun 2018 terdapat dugaan penyelewengan dana desa yang terjadi di Kota Denpasar terdapat dugaan penyalahgunaan dana desa di Desa Pemecutan Kaja, Kecamatan Denpasar Utara yang dilakukan oleh Kepala Desa sejak bulan Januari 2017 hingga Januari 2018, sehingga kerugian keuangan desa dalam kasus tersebut mencapai Rp 123 juta. Kasus penyalahgunaan Dana Desa kembali terjadi pada tahun tahun 2019 terdapat dugaan penyelewengan keuangan dana desa yang terjadi di Kota Denpasar. Berdasarkan hasil temuan dari Unit Satreskim Tipikor Polresta Denpasar, terdapat dugaan penyalahgunaan dana desa di Desa Dauh Puri Kelod, Kecamatan Denpasar Barat yang dilakukan oleh tiga oknum pejabat desa yaitu mantan Perbekel, Kaur Perencanaan, dan Bendahara Desa Dauh Puri Kelod dugaan korupsi ini bermula dari evaluasi internal dana APBDes 2017. Dari hasil audit internal ditemukan sisa lebih penggunaan anggaran (Silpa) sebesar 1,95 miliar dari jumlah itu, uang yang masih di tangan bendahara desa Rp877 juta, dipegang perbekal sebesar Rp8,5 juta dan Kaur Keuangan sebesar Rp102,82 juta. Dugaan penyelewengan ini muncul ketika selisih antara SILPA dengan dana yang masih dipegang yakni sebesar Rp1,035 miliar yang tidak jelas keberadaannya.

Berdasarkan laporan hasil pengawasan semester II yang dilakukan oleh Badan Pengawasan Keuangan dan Pembangunan (BPKP) Provinsi Bali, terdapat beberapa masalah pada pengelolaan dana desa di Kota Denpasar. Adapun permasalahan yang terjadi yaitu pada penatausahaan pengelolaan keuangan dana desa masih terdapat kesalahan dalam implementasi aplikasi siskeudes, terdapat kesalahan penganggaran dalam APBDes, BUMDesa belum menetapkan anggaran dasar dan anggaran rumah tangga serta belum dilakukannya pencatatan aset atas pekerjaan yang sudah selesai.

Pemerintah Desa dalam hal melaksanakan pengelolaan dana desa dituntut untuk menjalankan tugas secara akuntabel dan transparan agar tidak terjadi tindakan penyelewengan dana (Putri et al., 2018). Oleh karena itu, kompetensi sumber daya manusia yang berkualitas sangat dibutuhkan untuk melaksanakan tugas dan kewajiban dalam pengelolaan dana desa. Kompetensi sumber daya manusia merupakan kemampuan yang dimiliki seseorang atau individu dalam menghadapi situasi atau keadaan dalam melaksanakan tanggung jawab. Sistem pengelolaan dana desa yang baik, perangkat desa wajib memiliki sumber daya manusia yang berkualitas, didukung dengan latar belakang pendidikan dan pelatihan serta mempunyai pengalaman di bidang 
keuangan (Wardani dan Andriyani, 2018). Kompetensi Sumber daya manusia yang kurang dalam memahami dan menerapkan logika akuntansi akan dapat berpengaruh pada salah saji laporan dana desa yang dibuat dan ketidak sesuaian laporan dengan standar yang telah ditetapkan, oleh Pemerintah, sehingga informasi yang diterima oleh pengguna akan tidak tepat (Ferina et al., 2014). Penelitian yang dilakukan oleh Widiyarta et al., (2017) dan Laksmi dan Sujana (2019) menemukan bahwa kompetensi sumber daya manusia berpengaruh positif pada pencegahan fraud dalam pengelolaan dana desa.

Locus of Control dapat didefinisikan sebagai cara pandang seseorang pada suatu peristiwa dimana dia mampu atau tidak dalam mengendalikan peristiwa yang terjadi padanya (Lee, 2013). Locus of control dibagi menjadi dua kategori yaitu locus of control internal dan locus of control eksternal (Reiss dan Mitra, 1998). Individu yang memiliki locus of control internal percaya bahwa reaksi yang ditimbulkan adalah sesuatu yang disebabkan oleh sikap dari individur itu sendiri (Vishal, 2013). Sedangkan seseorang dengan locus of control eksternal meyakini bahwa seseorang tersebut dikendalikan oleh perilaku individu (internal) atau dikendalikan oleh kekuatan lain seperti kesempatan, keberuntungan, dan nasib (eksternal) (Karimi dan Alipour, 2011). Perbedaan sudut pandang pada locus of control bahwa seseorang dengan locus of control internal meyakini apa yang terjadi (baik kejadian positif atau negatif) merupakan konsekuensi dari tindakan orang itu sendiri, sehingga karena dalam pengendalian seseorang tersebut selalu berdasarkan pada peran serta tanggung jawabnya dalam setiap pengambilan keputusan. Sedangkan seseorang dengan locus of control eksternal meyakini bahwa kejadian dalam hidupnya dipengaruhi oleh takdir dan keberuntungan serta kekuasaan di luar dirinya, sehingga kejadian-kejadian yang terjadi pada dirinya adalah di luar pengendaliannya (Hastuti, 2007).

Lefcourt dan Martin (1984) mendefinisikan locus of control internal sebagai suatu keyakinan yang dihasilkan dari interaksi antara individu dan peristiwa-peristiwa yang terjadi adalah dari individu itu sendiri. Individu yang memiliki kompetensi tinggi apabila didukung oleh internal locus of control yang tinggi maka akan mampu mencegah terjadinya fraud. Dimana dalam hal ini , aparatur desa yang sudah berkompeten belum tentu dapat mencegah adanya fraud. Namun, dengan adanya locus of control internal sebagai kendali diri maka aparatur desa tidak akan melakukan fraud sehingga pencegahan fraud lebih optimal. Penelitian yang dilakukan oleh Dewi dan Damayanthi (2019) menemukan bahwa Locus of control internal berpengaruh positif pada pencegahan fraud dalam pengelolaan dana desa.

Fraud merupakan kecurangan yang menyimpang dan tindakan yang melanggar hukum dimana seseorang melakukannya dengan sengaja untuk menipu atau memberikan suatu gambaran yang keliru kepada pihak-pihak tertentu, baik dari luar ataupun dalam organisasi (Karyono, 2013:4). Tindakan fraud yang dilakukan oleh seseorang dapat menimbulkan banyak kerugian baik secara material maupun non material seperti hancurnya reputasi organisasi, kerugian keuangan negara, serta dampak-dampak negative lainnya (Indriyani et al., 2016). 
Ikatan Akuntan Indonesia (2018) menjelaskan terdapat dua jenis kecurangan akuntansi yang pertama salah saji yangtimbul dari kecurangan dalam pelaporan keuangan yaitu salah saji atau penghilangan secara sengaja jumlah atau pengungkapan dalam laporan keuangan yang bertujuan untuk mengelabui pemakai laporan keuangan dan yang kedua adalah salah saji yang timbul dari perlakuan tidak semestinyaa terhadap aktiva (sering kali disebut dengan penyalahgunaann atau penggelapan) yang berkaitan dengan pencurian aktiva entitas yang berakibat laporan keuangan tidak disajikan sesuai dengan Prinsip Akuntansi yang Berlaku Umum (PABU) di Indonesia. Menurut Association of Certified Fraud Examiners (2012:10) bentuk fraud terdiri dari: Kecurangan laporan keuangan (Financial statement fraud), penyalahgunaan aset (Asset Misappropriation), korupsi (corruption).

Pencegahan fraud dilakukan untuk meminimalisir tindakan kecurangan. Pencegahan fraud menurut Pusdiklatwas BPKP (2008:37) yaitu upaya teriintegritas yang dapat menekan terjadinya faktor penyebab fraud, yaitu memperkecil peluang terjadinya kesempatan untuk berbuat kecurangan, menurunkan tingkatan pegawai agar mampu memenuhi kebutuhannya, mengeleminasi alasan untuk membuat pembenaran atas tindak kecurangan yang dilakukan. Adapun strategi pencegahan fraud dalam pengelolaan keuangan menurut Kurniasari dkk., (2018) yaitu : mengawasi sistem pengawasan dan pengendalian, meningkatkan kultur organisasi, merumuskan nilai anti-fraud, menerapkan sistem reward dan punishment yang tegas, sosialisasi atas pendidikan anti-fraud bagi pegawai, membentuk agen perubahan .

Kompetensi sumber daya manusia mencakup kapasitas yaitu kemampuan seseorang individu dalam suatu organisasi atau suatu sistem untuk melakukan fungsi atau kewenangan untuk dapat mencapai tujuan yang efektif dan efisien (Sugiarti dan Yudianto, 2017). Berdasarkan fraud triangle theory ada tiga faktor yang mendorong terjadinya kecurangan diantaranya yaitu tekanan, peluang, dan rasionalisasi. Kompetensi sumber daya manusia yang baik dapat mencegah terjadinya fraud. Dalam pengelolaan keuangan desa pemerintah desa harus memiliki kompetensi sumber daya manusia yang berkualitas yang didukung latar belakang pendidikan, pengalaman, pelatihan, mengerti tentang akuntansi dan dana desa dan paham tentang aturan serta prosedur pengelolaan keuangan dana desa yang berlaku umum, dan memahami tujuan dana tersebut diberikan oleh Pemerintah. Hal tersebut diperlukan agar tidak terjadi kesalahan atau kekeliruan dalam pengelolaan laporan keuangan.

Penelitian yang dilakukan oleh Huslina (2015) menemukan bahwa kompetensi apatur berpengaruh positif pada sistem pencegahan fraud. Penelitian tersebut, didukung oleh penelitain yang dilakukan oleh Widiyarta et al., (2017) dan Laksmi dan Sujana (2019) yang menemukan bahwa kompetensi pemerintah desa berpengaruh positif pada pencegahan fraud dalam pengelolaan dana desa.

$\mathrm{H}_{1}$ : Kompetensi sumber daya manusia berpengaruh positif pada pencegahan fraud dalam pengelolaan dana desa.

Locus of control internal mengacu pada derajat di mana individu memandang peristiwa dalam kehidupannya sebagai konsekuensi dari 
perbuatannya, dengan demikian dapat dikontrol oleh individu itu sendiri. Trevino (1986) mengemukakan bahwa seseorang yang mempunyai locus of control internal yang tinggi berkeyakinan bahwa perilaku dan tindakannya ditentukan oleh peristiwa dalam hidupnya. Seseorang yang mempunyai locus of control internal berkeyakinan bahwa mereka mengendalikan apa yang terjadi pada mereka. Individu yang memilikli kompetensi tinggi apabila didukung oleh internal locus of control yang tinggi pula akan mampu mencegah terjadinya fraud. Dimana dalam hal ini, aparatur desa yang sudah berkompeten belum tentu dapat mencegah terjadinya fraud (Dewi dan Damayanthi, 2019). Namun, dengan adanya internal locus of control sebagai kendali diri maka aparatur desa tidak akan melakukan fraud sehingga pencegahan fraud lebih optimal. Hasil penelitian yang dilakukan oleh Dewi dan Damayanthi (2019) menemukan bahwa locus of control internal berpengaruh positif pada pencegahann fraud dalam pengelolaan dan desa.

$\mathrm{H}_{2}$ : Locus of control internal berpengaruh positif pada pencegahan fraud dalam pengelolaan dana desa.

\section{METODE PENELITIAN}

Populasi dalam penelitian ini adalah 27 Desa Dinas di Kota Denpasar. Samel dipilih dengan teknik non probability sampling berupa sampling total atau sensus. Pada penelitian ini, sampel yang digunakan adalah 27 Desa Dinas di Kota Denpasar Responden dalam penelitian ini sebanyak 108 orang diantaranya yaitu kepala desa, sekretaris desa, bendahara desa, dan badan permusyawaratan desa (BPD). Penelitian ini menggunakan teknik analisis regresi linier berganda sebagai teknik analisis datanya. Analisis data didasarkan pada kuesioner yang dinilai berdasarkan skala Likert 4 poin. Tahapan analisis data dalam penelitian ini adalah statistik deskriptif, uji asumsi klasik yang terdiri dari uji normalitas, uji multikolinieritas dan uji heteroskedastisitas serta uji analisis linier berganda, koefisien determinasi ( $\left.\mathrm{R}^{2}\right)$ uji $\mathrm{F}$ ( uji kelayakan model) dan uji t (uji hipotesis).

Persamaan regresi linier berganda dapat dirumuskan sebagai berikut.

$Y=\alpha+\beta_{1} X_{1}+\beta_{2} X_{2}+\beta_{3} X_{3}+\varepsilon$

Keterangan :

$\beta_{1}, \beta_{2}, \beta_{3}, \quad=$ Koefisien Regresi

$\mathrm{X}_{1} \quad=$ Kompetensi sumber daya manusia

$\mathrm{X}_{2} \quad=$ Locus of Control.

$\varepsilon \quad=$ Standar error

\section{HASIL DANPEMBAHASAN}

Analisis data deskriptif dilakukan untuk memberikan gambaran atau deskripsi mengenai variabel yang diteliti, terdiri dari kompetensi sumber daya manusia $\left(X_{1}\right)$ dan locus of control $\left(X_{2}\right)$ dan pencegahan fraud dalam pengelolaan dana desa.(Y). Hasil dari analisis data statistik deskriptif dapat dilihat pada Tabel 1. berikut. 
Tabel 1. Hasil Statistik Deskriptif

\begin{tabular}{lcrrrr}
\hline & N & Minimum & Maksimum & Rata-rata & Standar Deviasi \\
\hline Kompetensi SDM & 96 & 21,00 & 40,00 & 31,322 & 4,444 \\
Locus of control & 96 & 12,00 & 27,00 & 19,489 & 3,043 \\
Fraud & 96 & 15,00 & 27,00 & 22,406 & 2,569 \\
Valid N (listwise) & & & & &
\end{tabular}

Sumber : Data Penelitian, 2019

Nilai minimum pada variabel kompetensi sumber daya manusia sebesar 21,00 dan nilai maksimum sebesar 40,00. Nilai rata-rata pada variabel kompetensi sumber daya manusia sebesar 31,322. Nilai standar deviasi sebesar 4,444 lebih kecil dari nilai rata-ratanya, artinya penyimpangan data pada variabel kompetensi sumber daya manusia sangat kecil.

Nilai minimum pada variabel locus of control sebesar 12,00 dan nilai maksimum sebesar 27,00. Nilai rata-rata pada variabel locus of control sebesar 19,489. Nilai standar deviasi sebesar 3,043 lebih kecil dari nilai rata-ratanya, artinya penyimpangan data pada variabel locus of control sangat kecil.

Nilai minimum pada variabel pencegahan fraud dalam pengelolaan dana desa sebesar 15,00 dan nilai maksimum sebesar 27,00. Nilai rata-rata pada variabel pencegahan fraud dalam pengelolaan dana desa sebesar 22,406. Nilai standar deviasi sebesar 0,364 lebih kecil dari nilai rata-ratanya artinya penyimpangan. data pada variabel pencegahan fraud dalam pengelolaan dana desa sangat kecil.

Tabel 2. Hasil Analisis Regresi Linier Berganda

\begin{tabular}{|c|c|c|c|c|c|}
\hline \multirow[t]{2}{*}{ Variabel } & $\begin{array}{l}\text { Unstan } \\
\text { Coeffic }\end{array}$ & $\begin{array}{l}\text { rdized } \\
\text { its }\end{array}$ & $\begin{array}{l}\text { Standardized } \\
\text { Coefficients }\end{array}$ & \multirow[t]{2}{*}{ t hitung } & \multirow[t]{2}{*}{$\begin{array}{l}\text { Sig. } \\
\text { uji t }\end{array}$} \\
\hline & B & $\begin{array}{l}\text { Std. } \\
\text { Errorr }\end{array}$ & Beta & & \\
\hline (Constlant) & 7,094 & 1,318 & & 5,383 & 0,000 \\
\hline Kompetensi SDM $\left(X_{1}\right)$ & 0,211 & 0,060 & 0,364 & 3,518 & 0,001 \\
\hline Locus of control $\left(\mathrm{X}_{2}\right)$ & 0,236 & 0,068 & 0,280 & 3,466 & 0,001 \\
\hline R Square & 0,601 & & & & \\
\hline Adjusteed R Square & 0,587 & & & & \\
\hline F Statistik & 46,099 & & & & \\
\hline Signifikansi Uji F & 0,000 & & & & \\
\hline
\end{tabular}

Sumber : Data Penelitian, 2019

Berdasarkan hasil analisis regresi linier berganda seperti yang disajikan pada Tabel 2., maka dapat dibuat persamaan regresi sebagai berikut:

$\mathrm{Y}=7,094+0,211 \mathrm{X}_{1}+0,236 \mathrm{X}_{2}+\mathrm{e}$

Tabel 2. Menunjukkan koefisien regresi pada masing-masing variabel bebas yang diuji memiliki arah koefisien yang positif dan memiliki nilai signifikansi kurang dari 0,05.

Uji F atau uji kelayakan model digunakan untuk melihat apakah semua variabel bebas (independen) mempunyai pengaruh secara simultan terhadap variabel terikat (dependen) dengan tingkat signifikansi $\alpha=0,05$. Apabila tingkat signifikansi $\mathrm{F} \leq \mathrm{a}=0,05$ maka model ini dikatakan layak uji. Berdasarkan hasil penelitian uji $\mathrm{F}$ diperoleh nilai $\mathrm{F}_{\text {hitung }}$ sebesar 46,099 dengan signifkansi sebesar 0,000. Oleh karena nilai $F_{\text {hitung }}$ sebesar 46,099 dengan nilai signifikansi 0,000< 0,05, maka dapat disimpulkan bahwa model regresi yang digunakan pada penelitian ini adalah layak. Hasil ini mempunyai arti secara simultan kompetensi 
SDM dan Locus of Control berpengaruh signifikan pada pencegahan fraud dalam pengelolaan dana desa di Desa Dinas Kota Denpasar.

Hipotesis satu $\left(\mathrm{H}_{1}\right)$ dalam penelitian ini menyatakan bahwa Kompetensi SDM berpengaruh positif dan signifikan pada pencegahan fraud. Hasil perhitungan uji $t$ dapat diketahui.bahwa nilai koefisien regresi $X_{1}$ atau Kompetensi SDM adalah sebesar 0,211 dengan tingkat signifikansi sebesar 0,001 lebih kecil dari tingkat signifikansi $\alpha=0,05$. Hal ini menunjukkan bahwa kompetensi SDM berpengaruh positif pada pencegahan fraud dalam pengelolaan dana desa di Desa Dinas Kota Denpasar, yang berarti hipotesis 1 diterima. Hasil uji hipotesis yang telah dilakukan dan menunjukkan bahwa kompetensi sumber daya manusia berpengaruh positif pada pencegahan fraud dalam pengelolaan dana desa. Hasil penelitian ini sesuai dengan agency theory (Jensen dan Meckling, 1976) dalam Agency Theory menjelaskan bahwa terdapat hubungan antar principal dan agent, dimana principal menunjuk agent, untuk melaksanakan suatu jasa dan memberikan wewenang kepada agent untuk mengambil suatu keputusan. (Oliveira dan Filho, 2017) menjelaskan bahwa teori keagenan dapat diterapkan pada sektor publik. Menurut (Lane, 2013), hubungan antara principal dan agent merupakan pendekatan yang penting dalam menganalisis komitmen kebijakan publik. Pemerintah Desa dalam mengelol dana desa harus berdasarkan dengan peraturan dan regulasi yang telah di tetapkan oleh Pemerintah yaitu UndangUndang Republik Indonesia/Nomor 6 Tahun 2014 tentang Desa Peraturan Menteri Dalam Negeri Republik Indonesia Nomor 113 Tahun 2014 tentang Pengelolaan Keuangan Desa dan Keputusan Walikota Denpasar Nomor 188.45/345/HK/2018 tentang Penetapan Besaran Alokasi Dana Desa kepada Desa di Kota Denpasar.Kompetensi sumber daya manusia yang baik dapat mencegah terjadinya tindakan fraud. Dalam pengelolaan dana desa pemerintah desa harusl memiliki kompetensi sumber daya manusia yang berkualitas dan didukung latar belakang pendidikan, pengalaman, pelatihan, mengerti tentang akuntansi dan pengelolaan dana desa dan paham tentang peraturan serta prosedur dalam pengelolaan dana desa yang berlaku umum, dan memahami tujuan dana tersebut diberikan oleh Pemerintah. Hal tersebut diperlukan agar tidak terjadi kesalahan atau kekeliruan dalam pengelolaan laporan keuangan dana desa yang dibuat berdasarkan standar pengelolaan keuangan yang sudah ditetapkan oleh Pemerintah. Hasil penelitian ini searah dengan yang dilakukan oleh Huslina (2015), Widiyarta dkk., (2017) dan Laksmi dan Sujana (2019) yang menemukan bahwa kompetensi pemerintah desa berpengaruh positif pada pencegahan fraud dalam pengelolaan dana desa.

Hipotesis dua $\left(\mathrm{H}_{2}\right)$ dalam penelitian ini menyatakan bahwa locus of control berpengaruh positif dan signifikan pada pencegahan fraud. Hasil perhitungan uji $\mathrm{t}$ dapat diketahui bahwa nilai koefisien regresi $\mathrm{X}_{2}$ atau locus of control adalah sebesar 0,236 dengan tingkat signifikansi sebesar 0,001 lebih kecil dari tingkat signifikansi $a=0,05$. Hal ini menunjukkan bahwa locus of control berpengaruh positif dan signifikan pada pencegahan fraud dalam pengelolaan dana desa di Desa Dinas Kota Denpasar, yang berarti hipotesis kedua diterima. Hasil penelitian ini mendukung Teori Atribusi dimana teori ini menjelaskan bahwa ketika individu mengamati perilaku seseorang, 
individu tersebut berupaya untuk menentukan apakah perilaku tersebut disebabkan secara internal atau eksternal (Robbins dan Judge, 2008). Teori ini juga menjelaskan bahwa terdapat perilaku yang berhubungan dengan sikap dan karakteristik individu (Schuchter dan Levi, 2016).

Trevino (1986) menyatakan seseorang yang mempunyai locus of control internal yang tinggi berkeyakinan bahwa perilaku dan tindakannya ditentukan oleh peristiwa dalam hidupnya. Seseorang yang mempunyai locus of control internal percaya bahwa mereka mengendalikan apa yang terjadi pada mereka. Individu yang memiliki kompetensi tinggi apabila didukung oleh internal locus of control yang tinggi pula akan mampu mencegah terjadinya fraud. Aparatur desa yang sudah berkompeten belum tentu dapat mencegah adanya fraud (Dewi dan Damayanthi, 2019). Namun, dengan adanyan internal locus of control sebagai kendali diri maka aparatur desa tidak akan melakukan fraud sehingga pencegahan fraud lebih optimal. Hasil penelitian ini sejalan dengan penelitian yang dilakukan oleh Dewi dan Damayanthi (2019) menemukan bahwa locus of control internal berpengaruh positif pada pencegahan fraud dalam pengelolaan dan desa.

\section{SIMPULAN}

Kompetensi sumber daya manusia berpengaruh positifppada pencegahan fraud dalam pengelolaan dana desa. Hal ini berarti, kompetensi sumber daya manusia dalam pengetahuan, keahlian dan berperilaku dapat mencegah terjadinya tindakan fraud dalam pengelolaan dana desa locus of control Internal berpengaruh positif pada pencegahan fraud dalam pengelolaan dana desa. Apabila seseorang cenderung memiliki locus of control internal maka mereka akan lebih percaya diri denganokemampuan yang dimiliki dirinya sendiri dan tidak mudah terpengaruh oleh orang lain atau faktor lingkungan sekitar untuk melakukan tindakan kecurangan (fraud) serta melakukan tindakan suap. Bagi aparatur desa diharapkan dapat meningkatkan locus of control internal dalam pengelolaan dana desa karena dengan adanya Locus of control internal yang dimiliki aparatur desa sudah baik maka mengurangi niat aparatur desa untuk melakukan tindakan kecurangan (fraud). Bagi peneliti selanjutnya diharapkan mampu memperluas sampel penelitian tidak hanya di Kota Denpasar tetapi di Kabupaten lain di Bali untuk memperoleh perbandingan hasil yang lebih baik. Hasil penelitian dapat memberikan tambahan informasi mengenai pengaruh kompetensi sumber daya manusia dan locus of control pada pencegahan fraud dalam pengelolaan dana desa yang didukung dengan fraud triangel theory, teori keagenan dan teori atribusi. Hasil penelitian ini menyatakan bahwa kompetensi sumber daya manusia dan locus of control berpengaruh positif pada pencegahan fraud, hal ini sejalan dengan fraud triangle theory yang menjelaskan tiga faktor yang mendorong adanya tindakan fraud diantaranya tekanan, peluang dan rasionalisasi. Tekanan dapat membuat seseorang melakukan tindakan fraud. Tekanan tersebut bisa berasal dari berbagai aspek seperti tuntutan ekonomi, hutang, gaya hidup mewah dan lain sebagainya dimana tekanan tersebut dapat berasal dari faktor internal maupun eksternal seseorang. Adanya tekanan ini akan memicu tindakan kecurangan (fraud) yang dimaksudkan untuk memperoleh keuntungan secara pribadi namun dapat merugikan pihak lain. 
Tindakan kecurangan (fraud) ini dapat diminimalisir dengan adanya kompetensi sumber daya manusia yang baik dan locus of control.

\section{REFERENSI}

Aini, N., Prayudi, M. A., \& Diatmika, P. G. (2017). Pengaruh Perspektif Fraud Diamond Terhadap Kecenderungan Terjadinya Kecurangan (Fraud) Dalam Pengelolaan Keuangan Desa (Studi Empiris Pada Desa Di Kabupaten Lombok Timur). E-Jurnal Akuntansi Universitas Pendidikan Ganesha, 8(2). Retrieved from https://ejournal.undiksha.ac.id/index.php/S1ak/article/view/14583

Amiruddin, \& Kartini, G. P. (2017). The Performance Of Government Auditors In Perspectives Ethical Behavior And Tendency Of Accounting Fraud. IOSR Journal of Economics and Finance Ver. IV, 8(4), 35-42. https:// doi.org/10.9790/5933-0804043542

BPKP, P. (2008). Fraud Auditing. Pusat Pendidikan dan Pelatihan Badan Pengawas Keuangan dan Pembangunan.

Cressy, D.R . (1953). "Detecting and Predicting Financial Statement Fraud: The Effectiveness of The Fraud Triangle and SAS No 99". Journal of Corporate Governance and Firm Performance, (13), 53-81.

Dewi, L. A. M., \& Damayanthi, I. G. A. E. (2019). E-Jurnal Akuntansi Universitas Udayana Pemoderasi Pengaruh Kompetensi Aparatur Desa Dan Sistem Pengendalian Internal Pada Pencegahan Fraud Fakultas Ekonomi dan Bisnis Universitas Udayana ( Unud ), Bali, Indonesia PENDAHULUAN Adanya perubahan kekuasaan da. E-Jurnal Akuntansi Universitas Udayana, 26, 23752395.

Dorminey, J., A.S., F., M.-J, K., \& R.A., R. (2010). Beyond the fraud triangle: Enhancing deterrence of economic crimes. The CPA Journal, 17-23.

Examiners, A. of C. F. (2012). Report to the Nation On Occopational Fraud and Abuse.

Ferina, I. S., Burhanuddin, \& Lubis, H. (2014). Tinjauan Kesiapan Pemerintah Desa Dalam Implementasi Peraturan Menteri Dalam Negeri Nomor 113 Tahun 2014 Tentang Pengelolaan Keuangan Desa (Studi Kasus Pada Pemerintah Desa Di Kabupaten Ogan Ilir). Junal Manjemen Dan Bisnis Sriwijaya, 14(6). Retrieved from http://ejournal.unsri.ac.id/index.php/jmbs/article/view/3991/2036

Huslina, H., Islahuddin, \& Syah, N. (2015). Pengaruh Integritas Aparatur, Kompetensi Aparatur dan Pemanfaatan Teknologi Informasi Terhadap Efektivitas Sistem Pencegahan Fraud. Jurnal Magister Akuntansi, 4, 55-64.

Indonesia, I. A. (2018). Pertimbangan Atas Kecurangan Dalam Audit Laporan Keuangan SA Seksi 316. Jakarta: DSAK-IAI.

Indriyani, I., Suroso, A., \& Maghfiroh, S. (2016). Penerapan Konsep Fraud Diamond Theory Dalam Mendeteksi Perilaku Fraud. Simposium Nasional Auntansi XIX, Lampung.

Jensen, M. C.;Meckling, (1976). Theory of the firm: managerial behavioragency and ownership structure. Journal of Financial Economics, 3, 305-360. https:/ / doi.org/10.1016/0304-405X(76)90026-X

Karimi, R., \& Alipour, F. (2011). Reduce Job stress in Organizations: Role of Locus of Control. International Journal of Business and Social Science, 2(18), 
232-236.

Karyono. (2013). Forensic Fraud. Yogyakarta: Andi.

Laksmi, P. S. P., \& Sujana, I. K. (2019). Pengaruh Kompetensi SDM, Moralitas dan Sistem Pengendalian Internal Terhadap Pencegahan Fraud Dalam Pengelolaan Keuangan Desa. E-Jurnal Akuntansi Universitas Udayana, 26(3), 2155-2182. https:// doi.org/10.3997/2214-4609.201404048

Lane, J.-E. (2013). The Principal-Agent Approach to Politics: Policy Implementation and Public Policy-Making. Open Journal of Political Science, 03(02), 85-89. https:/ / doi.org/10.4236/ojps.2013.32012

Lee, H. W. (2013). locus of control, socialization and organizational identification. Actual Problem of Economics. 322-328.

Lefcourt, H. M., Martin, R. A., \& Saleh, W. E. (1984). Locus of control and social support: Interactive moderators of stress. Journal of Personality and Social Psychology, 47(2), 378-389. https:// doi.org/10.1037/0022-3514.47.2.378

Manossoh, H. (2016). Faktor-faktor Penyebab Terjadinya Fraud pada Pemerintah di Provinsi Sulawesi Utara, Emba. Jurnal Mahasiswa Universitas Sam Ratulangi Manado, 4(1), 484-495.

Oliveira, C. B., \& Filho, J. R. F. (2017). Agency problems in the public sector: The role of mediators between central administration of city hall and executive bodies. Revista de Administracao Publica, 51(4), 596-615. https://doi.org/10.1590/0034-7612171397

Putri, C. D., Yuniarta, G. A., \& Prayudi, M. A. (2018). Pengetahuan Peraturan, Kompetensi Sumber Daya Manusia, Monitoring dan Evaluasi Terhadap Efektivitas Sistem Pengendalian Internal Pemerintah Desa (Studi pada Desa Se-Kabupaten Karangasem). JIMAT (Jurnal Ilmiah Mahasiswa Akuntansi) Undiksha, 8(2). Retrieved from https:// ejournal.undiksha.ac.id/index.php/S1ak/article/view/13249/8334

Reiss, \& Mitra. (1998). No Title. The Effects of Individual Difference Factors on The Acceptability of Ethical and Unethical, 17, 1581-1593.

Robbins, S., \& Judge, T. (2008). Comportamiento Organizacional.

Schuchter, A., \& Levi, M. (2016). The Fraud Triangle revisited. Security Journal, 29(2), 107-121. https:// doi.org/10.1057/sj.2013.1

Sugiarti, E., \& Yudianto, I. (2017). Analisis Faktor Kompetensi Sumber Daya Manusia, Pemanfaatan Teknologi Informasi, dan Partisipasi Penganggaran Terhadap Akuntabilitas Pengelolaan Dana Desa (Survei Pada Desa-Desa di Wilayah Kecamatan Klari, Kecamatan Karawang Timur, Kecamatan Majalaya dan. Jurnal Mahasiswa Universitas Padjadjaran, (3), 580-590. Retrieved from https://repository.widyatama.ac.id/xmlui/handle/123456789/8578

Trevino, L. K. (1986). Ethical Decision Making in Organizations: A PersonSituation Interactionist Model. Academy of Management Review, 11(3), 601617. https://doi.org/10.5465/amr.1986.4306235

Vishal, M. (2013). A Study on Locus of Control and its Impact on Employees ' Performance. International Journal of Science and Research (IJSR), 2(12), 149151.

Wardani, D. K., \& Andriyani, I. (2018). Pengaruh Kualitas Sumber Daya Manusia, Pemanfaatan Teknologi Informasi, Dan Sistem Pengendalian Intern 
Terhadap Keandalan Pelaporan Keuangan Pemerintahan Desa Di Kabupaten Klaten. Jurnal Akuntansi, 5(2), 88-98. https:// doi.org/10.24964/ja.v5i2.270

Widiyarta, K., Herawati, N. T., \& Atmadja, A. T. (2017). Pengaruh Kompetensi Aparatur, Budaya Organisasi, Whistleblowing Dan Sistem Pengendalian Internal Terhadap Pencegahan Fraud Dalam Pengelolaan Dana Desa (Studi Empiris Pada Pemerintah Desa Di Kabupaten Buleleng). E-Journal S1 Ak Universitas Pendidikan Ganesha, 8(2), 1-12.

Wolfe, D. T., \& Hermanson, D. R. (2014). Print The Fraud Diamond: Co nsidering the Four Elements of Fraud. 12(Exhibit 1), 1-5. 